\title{
RESTLESS LEGS SYNDROME IN INSTITUTIONALIZED ELDERLY
}

\author{
Fábio Galvão Dantas', Jovany Luis Alves Medeiros², Kelly Soares Farias ${ }^{3}$, Clarissa Dantas Ribeiro ${ }^{3}$
}

\begin{abstract}
Restless legs syndrome (RLS) is characterized by disturbing leg sensations associated to sleep complaints and excessive daytime somnolence. In the elderly, it affects 10 to $35 \%$. Our objective was to determine the prevalence of RLS in institutionalized elderly, analyzing its relationship with clinical, laboratorial and neurophysiological features. We conducted a cross-sectional study of all the subjects under treatment on a chronic-care geriatric service by using face-to-face interviews, which include sleep complaints, the Epworth Sleepiness Scale and standardized questions addressing the four minimal criteria for RLS. The patients with RLS diagnosis received neurological examination, laboratorial tests and three of them, neurophysiological evaluation. The prevalence of RLS was $15.6 \%$. Women were more affected and sleep complaints were frequent. There was no significance on other clinical, laboratorial or neurophysiological findings. We conclude that RLS is a prevalent condition in elderly, may lead to sleep complaints and is often underdiagnosed.
\end{abstract}

KEY WORDS: restless legs syndrome, prevalence, elderly.

\section{Sindrome de pernas inquietas em idosos institucionalizados}

Resumo - Síndrome de pernas inquietas (SPI) é um distúrbio caracterizado por sensações parestésicas nos membros, aliviadas à sua movimentação ativa. A patologia se associa freqüentemente a distúrbios do sono, sendo especialmente prevalente em idosos (10 a 35\%), e pode estar associada a outras condições clínicas. Nosso objetivo foi determinar a prevalência da SPI em idosos institucionalizados, analisando queixas do sono e outras condições clínicas, bioquímicas e neurofisiológicas. Nós entrevistamos os idosos em regime de internato no Instituto São Vicente de Paula (Campina Grande, PB), utilizando questionários específicos para o sono, escala de sonolência de Epworth e um questionário para critérios mínimos para o diagnóstico de SPI. Os pacientes com o diagnóstico de SPI submeteram-se a exame neurológico, laboratoriais, e três deles, a exame neurofisiológico. A prevalência de SPI foi 15,62\%, afetando especialmente o sexo feminino. Queixas de sono e patologias associadas foram freqüentes, embora os testes laboratoriais e neurofisiológicos não tenham acrescentado dados significativos. Nós concluímos que SPI é prevalente em idosos, relaciona-se a alterações do sono e é freqüentemente subdiagnosticada.

PALAVRAS-CHAVE: sindrome de pernas inquietas, prevalência, idosos.

Restless legs syndrome (RLS) is a underdiagnosed neurological condition characterized by disturbing leg sensations that may lead to severe anxiety, depression, sleepdisrupting and excessive daytime somnolence (EDS). Symptoms are usually more severe late in the day and at bedtime'. RLS affects about 1.06 to $15 \%$ of the general population $^{2,3}$. Its prevalence increases with age ${ }^{4}$ and women are more frequently affected ${ }^{5}$.
In the elderly, RLS prevalence is about 10 to $35 \%^{6}$. Periodic limb movements (PLM) are frequently associated with $\mathrm{RLS}^{7}$, occurring in $4 \%$ to $11 \%$ in the elderly ${ }^{8}$ and requires polysomnographic confirmation. RLS is usually idiopathic, although it may be secondary to other pathological conditions like uremia, iron deficiency, Parkinson's disease, peripheral neuropathies and during pregnancy ${ }^{3}$, as well as to cardiovascular disease 9 . Although the neuropa-

\footnotetext{
Disciplina de Neurologia do Departamento de Fisioterapia da Universidade Estadual da Paraíba - Campus I - Campina Grande (UEPB): ${ }^{1}$ Médico Neurologista Especialista em Neurofisiologia Clínica (áreas de EEG e Polissonografia), habilitado em Medicina do Sono, Professor Mestre do Departamento de Fisioterapia da Universidade Estadual da Paraíba, Doutorando do Programa de Pós-Graduação em Neuropsiquiatria e Ciências do Comportamento da Universidade Federal de Pernambuco; ${ }^{2}$ Médico Neurologista Especialista em Neurofisiologia Clínica (área de EEG), Professor Adjunto Doutor do Departamento de Fisioterapia da Universidade Estadual da Paraíba; ${ }^{3}$ Acadêmica do Curso de Fisioterapia da Universidade Estadual da Paraíba. Pesquisa apoiada pelo Programa Institucional de Iniciação Científica/UEPB.
}

Received 20 December 2007, received in final form 15 April 2008. Accepted 27 April 2008.

Dr. Fábio Galvão Dantas - Departamento de Fisioterapia da Universidade Estadual da Paraíba - Avenida das Baraúnas 351 - $58109-753$ Campina Grande PB - Brasil.E-mail: fabiogalvaodantas@gmail.com 
thology is not completely understood, RLS seems to be related to abnormal dopamine control, as the symptoms improve with dopaminergic drugs ${ }^{6}$.

In the present study, we aimed to investigate RLS prevalence in institutionalized elderly, analyzing its relationship with insomnia, neurophysiological evaluation, clinical and laboratorial features.

\section{METHOD}

\section{Patients}

From October/2006 through April/2007, we conducted a cross-sectional study of 64 subjects under treatment on a chronic-care geriatric service called Instituto São Vicente de Paula (Campina Grande, PB, Brazil). This institution is maintained by private and public donations and receives poor and frequently abandoned elderly people. We excluded the patients younger than 65 years, restricted to bed, suffering with dementia and the subjects that did not cooperate with the interviewers. After that, were enrolled to study 32 patients.

\section{Procedures}

Two RLS-trained physiotherapy students (KSF and CDR) used standardized questions in face-to-face interviews. The positive or suspect cases were interviewed by one of us (FGD) to confirm the diagnosis. All the participants were interviewed using a questionnaire on sleep complaints and the Epworth Sleepiness Scale (ESS) to evaluate EDS. They also were asked on standardized questions addressing the four minimal criteria for RLS ${ }^{10,11}$ (Table 1). The symptoms might occur at least five times/month. All the patients with RLS diagnosis were submitted to neurological examination and received laboratory evaluations for blood cells, urea, creatinin, free serum iron, ferritin. Three patients were evaluated with electromyography performed by one of us (JLAM). The patients with RLS were then paired by gender and age to a control group (elderly of the same institution with negative diagnosis for RLS) for comparison of the laboratorial results.

\section{Statistical analysis}

Data were transcribed to the data bank of Windows Excel ${ }^{\circledR}$ software file and were grouped into variables. One-way repeated-measures analysis of variance (ANOVA) was used to compare
Table 1. Minimal criteria for restless legs syndrome diagnosis.

1. Unpleasant paraesthesias and disestesias of the legs or arms

2. Associated motor restlessness

3. Temporary improvement of symptoms with limbs movement or walking

4. Symptoms are more pronounced late in the day and at bedtime

the results of laboratorial tests. A value of $p<0.05$ was considered significant.

\section{Ethics}

This research protocol was approved by the Research Ethics Committee of the Paraiba State University (UEPB). All participating patients gave written informed consent.

\section{RESULTS}

Thirty-two patients met the inclusion criteria, 11 men (34.3\%) and 21 women (65.7\%). Five of them (15.6\%) had RLS, four women and one man. Table 2 depicts the main clinical features and electromyography results. The most prevalent sleep complaints were light sleep and insomnia. Table 3 depicts ESS results. One patient used sleep inductor and two complaint of snoring. The most frequent clinical pathologies were arterial hypertension (100\%), diabetes $(80 \%)$ and depression (20\%). Neurological, neurophysiologic and laboratorial examinations were normal.

\section{DISCUSSION}

In our sample, the prevalence of RLS was $15.6 \%$. This value is within the range of values reported by other authors: $9.8 \%^{3}$ and $19 \%^{12}$. Other research ${ }^{2}$ found a prevalence of $1.06 \%$ in Japanese elderly, which suggests that maybe racial aspects may play a role on prevalence differences. Controversially, others found a prevalence of $44 \%$ in elderly $^{13}$. These results emphasizes that RLS is more prevalent in elderly people and that more researches are needed to understand those differences.

Frequently, RLS is underdiagnosed because the symptoms may be attributed to other causes, like anxiety,

Table 2. Clinical features and electromyography (EMG) examination in patients with restless legs syndrome.

\begin{tabular}{cccccccccccc}
\hline Patient & Age/gender & Pain & Numbness & Cramps & Itching & MD & Frequency & SPB & IS & EMG \\
\hline 1 & $88 / \mathrm{M}$ & Yes & Yes & Yes & No & No & Daily & Yes & Move & Normal \\
2 & $71 / \mathrm{F}$ & Yes & Yes & Yes & Yes & No & $3 x /$ week & Yes & SH/SC & - \\
3 & $85 / \mathrm{F}$ & No & Yes & Yes & No & Yes & $2 x /$ week & Yes & Move & Normal \\
4 & $79 / F$ & Yes & No & No & Yes & No & Daily & Yes & Move $/$ MAS & - \\
5 & $73 / F$ & Yes & No & No & No & No & Daily & Yes & Move $/$ MAS & Normal \\
\hline
\end{tabular}

MD, movement disorders; SPB, symptoms are more pronounced at bedtime; IS, improving of symptoms with; SH, shower; SC, scratching; MAS, massage; $\mathrm{M}$, male; F, female. 
Table 3. EDS according to the ESS parameters in RLS patients.

\begin{tabular}{ccc}
\hline Patient & EDS score/classification & $\%$ \\
\hline 1 & 5 (normal) & 20 \\
2 & 4 (normal) & 20 \\
3 & 8 (normal) & 20 \\
4 & 15 (EDS) & 20 \\
5 & 15 (EDS) & 20 \\
\hline
\end{tabular}

EDS, excessive daytime somnolence; ESS, Epworth Sleepiness Scale; RLS, restless legs syndrome.

cramp or skin problems ${ }^{14}$. Our patients, for example, still did not have a correct diagnosis. RLS diagnosis is established on clinical criteria. Sometimes, the symptoms are not well described and it may lead to misinterpretation and a wrong diagnosis. One of the first researches ${ }^{15}$ found a very high prevalence of RLS in a population (29\%), but a questionnaire was used instead of a direct interview.

In our study, RLS was more prevalent in women. Other researches found similar results ${ }^{12,16,17}$. Yet this difference is not completely understood, hormones may play a role as RLS occurs in a higher prevalence in post-menopause and during the last trimester of pregnancy ${ }^{12}$. Conversely, it may reflect a greater life expectation for women ${ }^{18}$. In our series women were almost twice the number when compared to men.

Insomnia may affect 12 to $40 \%$ of elderly people ${ }^{19}$ and RLS is frequently associated to sleep complaints. Most of the RLS carriers look for medical assistance because of insomnia ${ }^{10,17}$. In our research, most of the patients complaint of insomnia, excessive daytime somnolence, enhanced sleeps latency and a not-refreshing sleep because of paraesthesias and motor restlessness. These sleep complaints were also reported by other authors ${ }^{10,17,20}$ and they emphasize the impact of RLS on the patients daily activities.

Serum and cerebrospinal fluid iron, ferritin and transferring deficiency have been reported in association with $\mathrm{RLS}^{21}$. It was suggested that the low brain iron concentration may result from a dysfunction of iron transportation from serum to CNS in idiopathic RLS patients ${ }^{22}$.

RLS has also been reported in association with maintenance dialysis ${ }^{21}$ and chronic renal pathologies ${ }^{23-27}$. In our study, all the RLS patients had normal renal studies, suggesting that these associations may be lacking, as reported by others ${ }^{26}$. We conclude that RLS is a prevalent condition in elderly and it may lead to sleep complaints. RLS is often underdiagnosed.

\section{REFERENCES}

1. Clark MM. Restless legs syndrome. J Am Board Fam Pract 2001;14:368-374.

2. Mizuno S, Miyaoka T, Inagaki T, Horiquchi J. Prevalence of restless legs syndrome in non-institutionalized Japanese elderly. Psychiatry Clin Neurosci 2005;59:461-465.

3. Zucconi M, Ferini-Strambi L. Epidemiology and clinical findings of restless legs syndrome. Sleep Med 2004;5:293-299.

4. Berger K, von Eckardstein A, Trenkwalder C, Rothdach A, Junker R, Weiland SKJ. Iron metabolism and the risk of restless legs syndrome in an elderly general population - the MEMO Study. Neurol 2002;249:1195-1199.

5. Hening W, Allen RP, Tenzer P, Winkelman JW. Restless legs syndrome: demographics, presentation, and differential diagnosis. Geriatrics 2007;62:26-29.

6. Milligan SA, Chesson AL. Restless legs syndrome in the older adult: diagnosis and management. Drugs Aging 2002;19:741-751.

7. Bjorvatn B, Leissner L, Ulfberg J, et al. Prevalence, severity and risk factors of restless legs syndrome in the general adult population in two Scandinavian countries. Sleep Med 2005;6:307-312

8. Hornyak M, Trenkwalder C. Restless legs syndrome and periodic limb movement disorder in the elderly. J Psychosom Res 2004;56:543-548.

9. Winkelman JW, Shahar E, Sharief I, Gottlieb DJ.Association of restless legs syndrome and cardiovascular disease in the Sleep Heart Health Study. Neurology 2008;70:35-42.

10. Walters AS. International Restless Legs Syndrome Study Group. Toward a better definition of the restless legs syndrome. Mov Disord 1995;10:634-642.

11. Allen R, Picchietti D, Hening W, et al. Restless legs syndrome diagnostic criteria, special considerations and epidemiology. Sleep Med 2003;4:101-119.

12. Rothdach A; Trenkwalder C; Haberstock J; Keil U; Berger K. Prevalence and risk factors of RLS in an elderly population. Neurology 2000;54:1064-1068

13. Campos HH, Bitthecourt LRA, Haidar MA, Tufik S, Baract EC. Prevalência de distúrbios do sono na pós-menopausa. Rev Bras Ginecol Obstet 2005;27;731-736.

14. Sawle G. Movement disorders during Sleep. In Sawle G (Ed). Movement disorders in clinical practice. Oxford: Isis Medical Media 1999;159-165.

15. Strang R. The symptoms of restless legs. Med J Aust 1967;1:1211-1213.

16. Earley CJ. Clinical practice restless legs syndrome. N Engl J Med 2003;348:2103-2109.

17. Montplaisir J, Boucher S, Poirier G, Lavigne G, Lapierre O, Lesperance P. Clinical, polysomnographic, and genetic characteristics of restless legs syndrome: a study of 133 patients diagnosed with new standard criteria. Mov Disord 1997;12:61-65.

18. WHO. World Helth Statistics 2007. In: www.who.int/whosis/whostat2007. pdf. Access in 04-07-2008.

19. Morin CM, Hauri PJ, Espie CA, Spielman AJ, Beusse DJ, Bootzin RR. Nonpharmacological treatment of chronic insomnia. Sleep 1999;22:1134-1156.

20. Phillips B, Young T, Finn L, Asher K, Hening WA, Purvis C. Epidemiology of restless legs symptoms in adults. Arch Intern Med 2000;160:2137-2141.

21. O'Keeffe ST. Secondary causes of restless legs syndrome in older people. Age Ageing 2005;34:349-352.

22. Mizuno S, Mihara T, Miyaoka T, Inagaki T, Horiguchi J. CSF iron, ferritin and transferrin levels in restless legs syndrome. J Sleep Res 2005; 14:43-47.

23. Mucsi I, Molnar MZ, Ambrus C, et al. Restless legs syndrome, insomnia and quality of life in patients on maintenance dialysis. Nephrol Dial Transplant 2005;20:571-577.

24. Goffredo-Filho GS, Gorine CC, Purysko AS, Silva HC, Elias IEF. Síndrome das pernas inquietas em pacientes em programa de hemodiálise em Petrópolis, RJ: freqüência, aspectos laboratoriais e comorbidades. Arq Neuropsiquiatr 2003;61:723-727.

25. Collado-Seidel V, Kohner R, Samtleben W, Hillebrand GF, Oertel WH, Trenkwalder C. Clinical and biochemical findings in uremic patients with and without restless legs syndrome. Am J Kidney Dis 1998;31:324-328.

26. Winkelman JW, Chertow GM, Lazarus JM. Restless legs syndrome in end-stage renal disease. Am J Kidney Dis 1996;28:372-378.

27. Miranda M, Araya F, Castillo JL, Duran C, Gonzalez F, Arís L. Síndrome de piernas inquietas: estudio clínico en población general adulta y en pacientes urémicos. Rev Med Chil 2001;129:179-186. 